Meta

Journal des traducteurs

Translators' Journal

\title{
“A House of Many Rooms:” Different Approaches of Two Translators of Flora Tristan's Pérégrinations d'une paria
}

\section{Grace A. Gomashie}

Volume 64, numéro 1, avril 2019

URI : https://id.erudit.org/iderudit/1065331ar

DOI : https://doi.org/10.7202/1065331ar

Aller au sommaire du numéro

Éditeur(s)

Les Presses de l’Université de Montréal

ISSN

0026-0452 (imprimé)

1492-1421 (numérique)

Découvrir la revue

Citer cet article

Gomashie, G. A. (2019). “A House of Many Rooms:” Different Approaches of Two Translators of Flora Tristan's Pérégrinations d'une paria. Meta, 64(1), 125-144. https://doi.org/10.7202/1065331ar
Résumé de l'article

Le présent article propose une analyse comparative de deux traductions de Pérégrinations d'une paria (1838), carnet de voyage de Flora Tristan qui relate son séjour au Pérou. La comparaison se fait entre la traduction anglaise par Jean Hawkes, Peregrinations of a Pariah, et la traduction espagnole par Emilia Romero, Peregrinaciones de una paria. Notre analyse révèle que les deux traductrices ont adopté des approches différentes et, donc, elles occupent deux pièces distinctes dans ce que Neubert et Shreve (1994) ont appelé la maison de traduction. L'analyse met en relief la façon dont elles représentent l'esclavage et le concept des femmes comme esclaves au sein du mariage. Elle s'appuie sur les théories et méthodes de traduction décrites dans Translating Slavery (1994/2009), dirigé par Kadish et Massadier-Kenney, dans lequel la traduction est étudiée sous différents angles : humaniste, critique et idéologique. Les traducteurs réunis dans ce volume abordent des questions sociales, comme la race et le genre, et, ce faisant, offrent différentes lectures du texte original. Dans le présent projet, on adopte une des approches proposées dans ce volume, une approche contrastive et comparative, pour examiner les différences entre les textes originaux et traduits, en se concentrant tout particulièrement sur les interventions des traductrices.
Ce document est protégé par la loi sur le droit d'auteur. L’utilisation des services d'Érudit (y compris la reproduction) est assujettie à sa politique d'utilisation que vous pouvez consulter en ligne.

https://apropos.erudit.org/fr/usagers/politique-dutilisation/ 


\title{
"A House of Many Rooms:" Different Approaches of Two Translators of Flora Tristan's Pérégrinations d'une paria
}

\author{
GRACE A. GOMASHIE \\ Western University, London, Canada \\ ggomashi@uwo.ca
}

\begin{abstract}
RÉSUMÉ
Le présent article propose une analyse comparative de deux traductions de Pérégrinations d'une paria (1838), carnet de voyage de Flora Tristan qui relate son séjour au Pérou. La comparaison se fait entre la traduction anglaise par Jean Hawkes, Peregrinations of a Pariah, et la traduction espagnole par Emilia Romero, Peregrinaciones de una paria. Notre analyse révèle que les deux traductrices ont adopté des approches différentes et, donc, elles occupent deux pièces distinctes dans ce que Neubert et Shreve (1994) ont appelé la maison de traduction. L'analyse met en relief la façon dont elles représentent l'esclavage et le concept des femmes comme esclaves au sein du mariage. Elle s'appuie sur les théories et méthodes de traduction décrites dans Translating Slavery (1994/2009), dirigé par Kadish et Massadier-Kenney, dans lequel la traduction est étudiée sous différents angles: humaniste, critique et idéologique. Les traducteurs réunis dans ce volume abordent des questions sociales, comme la race et le genre, et, ce faisant, offrent différentes lectures du texte original. Dans le présent projet, on adopte une des approches proposées dans ce volume, une approche contrastive et comparative, pour examiner les différences entre les textes originaux et traduits, en se concentrant tout particulièrement sur les interventions des traductrices.
\end{abstract}

\section{ABSTRACT}

This paper performs a comparative analysis of two translations of Flora Tristan's travelogue to Peru, Pérégrinations d'une paria (1838), namely Jean Hawkes' English translation, Peregrinations of a Pariah and Emilia Romero's Spanish version, Peregrinaciones de una paria. This analysis reveals that the two translators chose different approaches to their task, thus inhabiting two different rooms in the house of translation (Neubert and Shreve 1994). Special emphasis is placed on their representations of slavery and the concept of women as slaves in marriage. This project relies on the translation theories and practice described in Kadish and Massadier-Kenney's edited volume, Translating Slavery, which presents translation from a humanistic, critical, and ideological point of view. The translators writing in this volume incorporate social issues such as race and gender, providing different perspectives on the original text. This project uses one of their approaches: that is, a contrastive and comparative method, examining the differences between the original and the translated texts, especially looking at the interventions of the translators.

\section{RESUMEN}

Este artículo realiza un análisis comparativo de dos traducciones del diario de viaje a Perú, Pérégrinations d'une paria (1838) de Flora Tristan: la traducción inglesa de Jean Hawkes, Peregrinations of a Pariah, y la versión española de Emilia Romero, Peregrinaciones de una paria. Este análisis revela que las dos traductoras eligieron distintos enfoques al traducir el texto, por lo tanto, viven en dos diferentes cuartos en la casa de traducción (Neubert y Shreve, 1994). Se pone especial énfasis en sus representaciones de la esclavitud y el concepto de mujeres como esclavas en el matrimonio. Este proyecto se basa 
en las teorías y prácticas de traducción, descritas en el volumen editado de Kadish y Massadier-Kenney, Translating Slavery, que presenta la traducción desde la perspectiva humanística, crítica e ideológica. Los traductores en el volumen incorporaron asuntos sociales como la raza y el género, dando perspectivas diferentes al texto original. Este proyecto utiliza un enfoque, contrastivo y comparativo, examinando las diferencias entre los textos originales y traducidos, en especial, estudiando las intervenciones de los traductores.

\section{MOTS CLÉS/KEYWORDS/PALABRAS CLAVE}

Pérégrinations d'une paria, visibilité de traducteur, genre, race, traduction d'esclavage Peregrinations of a Pariah, translator's visibility, gender, race, translating slavery Peregrinaciones de una paria, visibilidad de traductor, genero, raza, traducción de esclavitud

It is our firm conviction that translation is a 'house of many rooms' and that these different rooms are often simply different discourses and perspectives on a common object of interest - translation. (Neubert and Shreve 1994: xii)

\section{Introduction}

This paper performs a comparative analysis of two translations of Flora Tristan's travelogue to Peru, Pérégrinations d'une paria (1838), ${ }^{1}$ namely Jean Hawkes' English translation, Peregrinations of a Pariah $(1838 / 1986)^{2}$ and Emilia Romero's Spanish version, Peregrinaciones de una paria (1838/2003). ${ }^{3}$ This analysis reveals that the two translators chose different approaches to their task, thus inhabiting two different rooms in the house of translation (Neubert and Shreve 1994: xii). Special emphasis is placed on their representations of slavery and the concept of women as slaves in marriage.

A brief summary of Pérégrinations d'une paria provides some context for the current project. In her two-volume book, Flora Tristan wrote a first-person account of her travels in Peru from 1833 to 1834. To help her readers understand the perspectives of her travelogue, French-born Tristan narrated the events and circumstances that led to her travel to Peru in the Preface and Foreword of her account. Flora was the illegitimate daughter of Don Mariano Tristan de Moriscos, a Peruvian creole of noble birth who served in the Spanish army, and Therese Laisnay, a French woman. The untimely death of Don Mariano left Flora and her mother in dire financial straits. Flora was then forced by her mother to marry her employer Andre Chazal, a lithographer. This abusive and disastrous marriage resulted in three children of whom two survived. To escape her abusive husband, thirty-year-old Flora undertook a voyage to Peru on April 7, 1833 to seek the protection of her father's family, headed by Don Pío de Tristan. Before this, she had supported her children for eight years after separating from her husband. Upon the counsel of one of her paternal relatives, she embarked on this peregrination to Peru, disguised as an unmarried woman. Her untenable situation as a married woman, enforced by France's laws against divorce, as well as the need for financial security motivated her travels. Her pilgrimage to Peru was a story of claiming her paternal legitimacy and inheritance. Tristan stated that, contrary to her expectations, she was denied her paternal rights by her uncle Pío and was given but a meager monthly allowance. However, Flora focused her energy on 
advocating for women's rights, a calling that she continued after her return to France in 1835. In Pérégrinations d'une paria (1838), she identified with women who were oppressed under patriarchy and she celebrated female superiority, leadership, and excellence. She also criticized heavily patriarchal systems and religious institutions, as well as the seeming lack of leadership and progress in post-independence Peru. She saw the condition of women as similar to slavery, with both slaves and women being in need of emancipation. In her book, slavery is not only a construct concerning race, but also gender. The section below describes the theoretical framework of the article.

\section{Theoretical framework}

This project relies on the translation theories and practice described in Kadish and Massardier-Kenney's edited volume, Translating Slavery (1994/2009). The volume presents translation from humanistic, critical, and ideological points of view. The translators writing in this volume incorporate social issues such as race and gender, providing different perspectives on the original text. This project uses one of their approaches: that is, a contrastive and comparative method, examining the differences between the original and the translated texts, especially looking at the interventions of the translator.

Furthermore, Massardier-Kenney's chapter on translation theory and practice asserts that the principal relevance of any (theory of) translation is its ideological and critical outlook. She portrays translation as a "legitimizing process for the writer" (Massardier-Kenney 1994/2009: 5) through which the translator actively chooses the text she translates. In addition to the authority brought to the text through translation, meaning is created, the literary reputation of the author is stated, the colonized, the oppressed, the forgotten are given a voice; and the difference and hybridity in cultures are celebrated. She recommends that a translator be deeply invested in issues of race and gender before translating texts of this nature. Not only should a translator maintain the voice and spirit of the original text, s/he should also be conscious of the usage and history of racially sensitive terms. This underscores the fact that translation is a self-reflective process where the translator determines whether to be faithful to the source text, or radicalize or neutralize the differences in the original text. The following section describes in greater detail the methodology used in this project. A brief translation history of Pérégrinations, with the target texts, is provided, in addition to analysis of selected passages from volumes I and II.

\section{Method}

\subsection{Selected texts}

The two-volume Pérégrinations d'une paria was published in 1838 and contains over 900 pages. Volume I has eight chapters, as well as other sections such as a Dedication, a Preface, and a Foreword; Volume II has ten chapters. Soon after the publication of Pérégrinations in 1838, it underwent ten translations (Cross 2007). However, after Tristan's death in 1844, interest in her work faded and it would take more than 75 years for Pérégrinations to be available in print again in France. Hawkes (1986a) also writes that Tristan's writings fell into oblivion after her death and had to be 
rescued twice in the $20^{\text {th }}$ century: first, interest in Tristan surged in France after the First World War which coincided with the revival of the women's suffrage movement, and secondly, interest increased in the 1970s, thanks to the rise of feminist studies. A search for Pérégrinations in the World Cat database reveals about 150 editions published between 1838 and today; some are reprints and abridged versions of the original, while others are full or abridged translations in English, Spanish, German, and Japanese. The two female translators analysed in the current project both used the original French edition as their source text. Emilia Romero was the first to completely translate the two volumes of Pérégrinations into Spanish in 1925 (André and Bueno 2014). Other editions of her Spanish translation appeared in $1941^{4}$ (with the selection, prologue, and notes by Luis-Alberto Sanchez) and $1946^{5}$ (with a prologue by Jorge Basadre). Another edition appeared in Peru in 1946 and included translator notes. This version has subsequently been reproduced in other editions, including the 2003 edition considered here. The 2003 edition was jointly published by the Centro de la Mujer Peruana Flora Tristan and the UNMSM Press as a tribute to Tristan. Its prologue was written by Mario Vargas Llosa, a knowledgeable scholar on Tristan and her famous grandson Paul Gauguin, and its introduction was written by Francesca Denegri.

To date, there are no complete English translations of Pérégrinations d'une paria. The two English translations by Jean Hawkes (1986) and Charles Salis (1986) ${ }^{6}$ are abridged versions. Both versions have a translator's note explaining the choice for an abridged version. Salis' French source text was the Maspero (1980) edition ${ }^{7}$ which contained about three-quarters of Tristan's original text. In Salis' translation, Richardson comments that the abridgment was necessary because Tristan was repetitive and it offered "a racier, more readable account, while losing nothing of great value" (Richardson 1986: viii). The English translation chosen for this project is Jean Hawkes's version (1986), published by Virago, a feminist press. Hawkes eliminated about a third of the original text, a choice that she justified in her introduction. She explains that "considerations of space and economy have obliged me to reduce it by more than one-third, much to my regret" (Hawkes 1986b: xxix). Hawkes goes further to indicate the materials she cut out including the preliminary texts in volume I, minor characters, moralising descriptions, a political conversation and letters. For this project, the Spanish translation of Romero $(1946,2003)$ was chosen because it is complete and has been republished many times. Hawkes' translation into English was chosen because it is widely used for academic analysis, and a complete English translation is not available. The strengths and weaknesses of both versions were assessed.

\subsection{Analysis}

As was mentioned earlier, structurally, the eight chapters of the first volume are preceded by three preliminary sections (a Dedication to Peruvians, a Preface, and a Foreword), and there are ten chapters in the second volume. Hawkes' English translation (Tristan 1838/1986) contains all eighteen chapters of the original, albeit abridged, preceded by a Translator's Introduction and Note. Hawkes omitted the three preliminary sections which explain Tristan's radical stance. Romero's complete Spanish translation, Peregrinaciones de una paria (Tristan 1838/1946, 1838/2003), includes the three preliminary sections, in addition to a tribute by Vivian Vargas of 
the Centro de la Mujer Peruana Flora Tristan. Additionally, this version contains footnotes by Romero. The passages selected for the current project focus largely on Tristan's overarching theme of liberation in the face of oppression or slavery. The analysis begins with the preliminary sections of Volume I, followed by selected portions of the main narrative in volumes I and II.

\subsubsection{Preliminary sections (Dedication, Preface, and Foreword)}

The first volume of Tristan's book contains three preliminary sections: Dedication to Peruvians, Preface, and Foreword. For many books, such preliminary sections may be of limited importance. However, in the case of Tristan's book, those three preliminary sections are vital for the deliberate construction of a public image of Tristan, and hence their total omission in the English translation by Hawkes defeats Tristan's purpose in writing them. Guiñazú's (2002) study of the Dedication, Preface, and Foreword highlights their importance for Tristan as they justified her actions and tried to garner the support of her readers in her favour. In Guiñazú's (2002) words:

Los tres textos que preceden el relato de viaje: la dedicatoria, el prefacio y el prólogo responden a un cuidadoso montaje de autopresentación y justificación por parte de la autora. Escritos después de terminado[sic] el relato, presentan la imagen pública que Tristán quiere para sí. Surge aquí la figura de la autora experimentada que escribe con conocimiento de causa y que difiere de la imagen de la viajera presentada en el transcurso del relato. (Guiñazú 2002)

What warrants translation in these sections? Beginning with the dedication, $A u x$ Péruviens, Tristan predicted that her travel account would offend the national pride of many Peruvians and that she might be perceived as ungrateful after the warm welcome she received in Peru. But more importantly, she uses her Peruvian identity to justify her criticism and advice to her fellow citizens:

1) J'ai dit, après l'avoir reconnu, qu'au Pérou, la haute classe est profondément corrompue, que son égoïsme la porte, pour satisfaire sa cupidité, son amour du pouvoir et ses passions, aux tentatives les plus antisociales; j'ai dit aussi que l'abrutissement du peuple est extrême dans toutes les races dont il se compose... Instruisez donc le peuple, c'est par là que vous devez commencer pour entrer dans la voie de la prospérité; établissez des écoles jusque dans le plus humble des villages, c'est actuellement la chose urgente; employez-y toutes vos ressources...Prenez des mesures pour faciliter les apprentissages; l'homme qui a un métier n'est plus un prolétaire; à moins que des calamités publiques ne le frappent, il n’a jamais besoin d'avoir recours à la charité de ses concitoyens; il conserve ainsi cette indépendance de caractère si nécessaire à développer chez un peuple libre... Votre compatriote et amie.

(Tristan 1838a: vii-xi)

a) He dicho, después de haberlo comprobado, que en el Perú la clase alta está profundamente corrompida y que su egoísmo la lleva, para satisfacer su afán de lucro, su amor al poder y sus otras pasiones, a las tentativas más antisociales. He dicho también que el embrutecimiento del pueblo es extremo en todas las razas que lo componen... Instruid, pues, al pueblo; es por allí por donde debéis empezar para entrar en la vía de la prosperidad. Estableced escuelas hasta en las aldeas más humildes: esto es lo urgente en la actualidad. Emplead en ello todos vuestros recursos...Tomad medidas para facilitar el aprendizaje. El hombre que tiene un oficio no es ya un proletario. A menos que le hieran calamidades públicas, no tiene ya necesidad de recurrir a la caridad de sus conciudadanos. 
Conserva así esa independencia de carácter tan necesaria de que se desarrolle en un pueblo libre... Vuestra compatriota y amiga.

(Tristan 1838/2003: 71-72, translated by Romero)

As demonstrated in the text above, Emilia Romero performed a literal translation, usually mirroring the sentence structure and using a word choice similar to that of the original text. Her choice of Spanish words and phrasing closely matches the French. Illustrations can be seen in Romero's translation of the upper class as deeply corrupt (profondément corrompue, profundamente corrompida), motivated by selfishness (égoïsme, egoísmo) to carry out antisocial endeavours (tentatives antisociales, tentativas antisociales). All things considered, her translation is impeccable and she faithfully transmits Tristan's main message that Peru's local populace was oppressed and in need of liberation.

In the Préface, Tristan justified revealing her marital woes, a social taboo in her time. She claimed that her revelation was motivated by truth and not publicity, and she encouraged women to follow her example by narrating their trials. She also criticized women who fictionalized their life histories using male pseudonyms, lamenting the apparent lack of impact of this practice in changing the social order. She believed that speaking the truth about one's experiences and revealing the evil practices of others helped to prevent future occurrences. Most importantly, she linked the oppression of women to slavery and posited that women around the world were enslaved.

2) Existe-t-il une action plus odieuse que celle de ces hommes qui, dans les forêts de l'Amérique, vont à la chasse des nègres fugitifs pour les ramener sous le fouet du maître! La servitude est abolie, dira-t-on dans l'Europe civilisée. On n'y tient plus, il est vrai, marché d'esclaves en place publique; mais dans les pays les plus avancés, il n'en est pas un où des classes nombreuses d'individus n'aient à souffrir d'une oppression légale. Les paysans en Russie, les juifs à Rome, les matelots en Angleterre, les femmes partout; oui, partout où la cessation du consentement mutuel, nécessaire à la formation du mariage, n'est pas suffisante pour le rompre, la femme est en servitude.

(Tristan 1838a: xxiii-xxiv)

a) ¿Existe acción más odiosa que la de esos hombres que en las selvas de América, van a la caza de negros fugitivos para traerlos de nuevo bajo el látigo del amo? La esclavitud está abolida, se dirá, en la Europa civilizada. Ya no hay, es cierto, mercados de esclavos en las plazas públicas; pero entre los países más avanzados no hay uno en el cual clases numerosas de individuos no tengan mucho que sufrir de una opresión legal: los campesinos en Rusia, los judíos en Roma, los marineros en Inglaterra, las mujeres en todas partes. Sí, en todas partes en donde la cesación del consentimiento mutuo y necesario a la formación del vínculo matrimonial no es suficiente para romperlo, la mujer está en servidumbre.

(Tristan 1838/2003: 77, translated by Romero)

Once again, Romero does a good job in transmitting Tristan's message that women are facing a fate similar to slavery by using similar words. Furthermore, Tristan blamed social prejudices for making women suffer in silence and portrayed herself as a pioneer for attacking the status quo. Once again, she universalized the oppression of women. Tristan is sometimes criticized for being too dramatic, hyperbolic, duplicitous, and self-important (Law-Sullivan 2010: 65), primarily for comparing her personal trials to more serious issues such as slavery. 
3) Les préjugés qui règnent au milieu de la société semblent avoir glacé leur courage; et tandis que les tribunaux retentissent des demandes adressées par des femmes, afin d'obtenir soit des pensions alimentaires de leurs maris, soit leur séparation, pas une n'ose élever la voix contre un ordre social qui les laissant sans profession, les tient dans la dépendance, en même temps qu'il rive leurs fers par l'indissolubilité du mariage... Que les femmes dont la vie a été tourmentée par de grandes infortunes fassent parler leurs douleurs; qu'elles exposent les malheurs qu'elles ont éprouvés par suite de la position que les lois leur ont faite et des préjugés dont elles sont enchaînées; mais surtout qu'elles nomment... Beaucoup de femmes vivent séparées de fait d'avec leurs maris, dans les pays où le catholicisme de Rome a fait repousser le divorce. Ce n'est donc pas sur moi personnellement que j'ai voulu attirer l'attention, mais bien sur toutes les femmes qui se trouvent dans la même position, et dont le nombre augmente journellement. Elles éprouvent des tribulations, des souffrances de même nature que les miennes, sont préoccupées du même ordre d'idées et ressentent les mêmes affections.

(Tristan 1838a: xxvi-xxix; author's emphasis)

a) Los prejuicios que reinan en la sociedad parecen haber paralizado su valor, $y$ mientras en los tribunales repercuten las demandas dirigidas por las mujeres, ya sea para obtener pensiones alimenticias de sus maridos o su separación de ellos, ninguna se atreve a levantar la voz contra un orden social que, dejándolas sin profesión, las mantiene en la dependencia, al mismo tiempo que remacha sus cadenas con la indisolubilidad del matrimonio... ¡Qué las mujeres cuya vida ha sido atormentada por grandes infortunios hagan hablar sus dolores! Que expongan las desgracias sufridas como consecuencia de la posición que les han deparado las leyes y los prejuicios que las encadenan; pero que hablen.... Muchas mujeres viven, de hecho, separadas de sus maridos, en los países en donde el catolicismo de Roma ha hecho rechazar el divorcio. No es, pues, sobre mí, personalmente, que quiero atraer la atención, sino sobre todas las mujeres que se encuentran en la misma posición y cuyo número aumenta diariamente. Ellas pasan por tribulaciones y por sufrimientos de misma naturaleza que los míos, están preocupadas por la misma clase de ideas y sienten los mismos afectos.

(Tristan 1838/2003: 77-79, translated by Romero)

Scholars such as Susan Grogan (1998) have indicated that Tristan had a tendency to exaggerate her uniqueness, as she was certainly not the first woman to have asked for a divorce or to have gone against the social order. The French feminists of her era, with whom she was familiar, had already been vocal in this area and had been the first in France to appropriate the term white slaves to represent the social condition of women. Nonetheless, translators have a responsibility to the author to translate her views. Romero achieved this by performing a complete and literal translation into Spanish, while Hawkes chose not to include the Preface in her English translation.

Finally, in the third preliminary section, Avant-Propos, Tristan went into details about her life, by recounting the circumstances that propelled her travel to Peru:

4) Ma mère est Française: pendant l'émigration elle épousa en Espagne un Péruvien; des obstacles s'opposant à leur union, ils se marient clandestinement, et ce fut un prêtre français émigré qui fit la cérémonie du mariage dans la maison qu’occupait ma mère. J’avais quatre ans lorsque je perdis mon père à Paris. Il mourut subitement, sans avoir fait régulariser son mariage, et sans avoir songé à y suppléer par des dispositions testamentaires. Ma mère n'avait que peu de ressources pour vivre et nous élever, mon jeune frère et moi; elle se retira a la campagne...nous revînmes à 
Paris, où ma mère $\underline{\text { m'obligea }}$ d'épouser un homme que je ne pouvais ni aimer ni estimer. A cette union je dois tous mes maux... J'appris, pendant ces six années d'isolement, tout ce qu'est condamnée à souffrir la femme séparée de son mari au milieu d'une société qui, par la plus absurde des contradictions, a conservé de vieux préjugés contre les femmes placées dans cette position, après avoir aboli le divorce et rendu presque impossible la séparation de corps.

(Tristan 1838a: xxxv-xxxvi; author's emphasis)

a) Mi madre es francesa. Durante la emigración, se casó en España con un peruano. Como algunos obstáculos se oponían a su unión, se casaron clandestinamente y fue un sacerdote francés emigrado quien celebró la ceremonia del matrimonio en la casa que ocupaba mi madre. Tenía yo cuatro años cuando perdí a mi padre en París. Murió súbitamente, sin haber regularizado su matrimonio y sin haber pensado en reemplazarlo con disposiciones testamentarias. Mi madre tenía pocos recursos para vivir y educarnos a mi hermano menor y a mí. Se retiró al campo... Regresamos a París, en donde mi madre me obligó a casarme con un hombre a quien no podía amar ni estimar. A esta unión debo todos mis males... Supe durante esos seis años de aislamiento todo lo que está condenada a sufrir la mujer que se separa de su marido en medio de una sociedad que, por la más absurda de las contradicciones, ha conservado viejos prejuicios contra las mujeres colocadas en esta posición, después de haber abolido el divorcio y hecho casi imposible la separación de cuerpos.

(Tristan 1838/2003: 83, translated by Romero)

Tristan's fraught emotional and mental state, caused by her untenable situation and constant anxiety, nearly made her commit suicide:

5) Ma vie était un supplice de tous les instants. Sensible et fière à l'excès, j'étais continuellement froissée dans mes sentiments, blessée et irritée dans la dignité de mon être. Si ce n'eût été l'amour que je portais à mes enfants, ... sans ce devoir sacré dont mon cœur était profondément pénétré, que Dieu me le pardonne!... je me serais tuée.

(Tristan 1838a: xxxvii-xxxviii)

a) Mi vida era un suplicio de todos los instantes. Sensible y orgullosa con exceso, me sentía continuamente ofendida en mis sentimientos y herida e irritada en la dignidad de mi ser. Si no hubiese sido por el amor que tenía a mis hijos, ... sin ese deber sagrado que penetraba profundamente en mi corazón ¡qué Dios me perdone! ¡me habría dado la muerte...!

(Tristan 1838/2003: 85, translated by Romero)

Romero's faithful translation into Spanish is accompanied by her footnotes which supply additional information about the people mentioned, the historical context including the exact dates when events occurred, and recommended supplementary readings. One of the translator's footnotes contradicts Tristan's claim that she never loved her husband. Romero refers readers to La vie et l'œuvre de Flora Tristan (1925), in which Jules L. Puech documents that Andre Chazal, Tristan's husband, presented love letters written to him by Tristan during their long judicial battle. These letters proved that Tristan and Chazal had been lovers before marriage, perhaps providing the real reason for her being forced to marry him. Hence, Romero not only translates but critically analyses the source text. 
The latter part of the Avant-Propos demonstrates that Tristan's decision to travel to Peru was not taken lightly. She was hesitant about travelling because of uncertainty about what awaited her at sea and upon arrival, and because of her love for her daughter. However, she blamed her status as a slave for propelling her to travel to Peru.

6) Quitter mon pays que j'aimais de prédilection; quitter ma fille qui n'avait que moi pour appui; exposer ma vie, ma vie qui m'était à charge, parce que je souffrais, parce que je n'en pouvais jouir que furtivement, mais qui m'eût apparu belle et radieuse si j'avais été libre; enfin, faire tous ces sacrifices, affronter tous ces dangers, parce que j'étais liée à un être vil qui me réclamait comme son $\underline{\text { esclave! }}$. Oh! ces réflexions faisaient bondir mon cœur d'indignation; je maudissais cette organisation sociale qui, en opposition avec la Providence, substitue la chaîne du forçat au lien d'amour et divise la société en serves et en maîtres.

(Tristan 1838a: xliv; author's emphasis)

a) Dejar mi país que amaba con predilección; abandonar a mi hija que no tenía más apoyo que el mío; exponer mi vida, mi vida que era una carga para mí, porque sufría y porque no podía gozarla sino furtivamente, pero que de haber sido yo libre me habría parecido bella y radiante. En fin, hacer todos esos sacrificios y afrontar todos esos peligros, porque estaba unida a un ser vil que me reclamaba como a su esclava. ¡Oh! esas reflexiones hacían saltar indignado a mi corazón. Maldecía esta organización social que, opuesta a la Providencia, sustituye con la cadena del forzado el lazo del amor y divide la sociedad en siervos y en amos.

(Tristan 1838/2003: 89-90, translated by Romero)

The selected passages thus far show Tristan's personal struggles in an alleged unhappy marriage and her fight against the oppression of women. She blamed society and the laws that kept women dependent on men. In her view, the indissolubility of marriage made women second-rate citizens and, in her words, a slave bound by the chains of her husband. Hence, the Dedication, Preface, and Foreword portray the philosophy, beliefs, and projected image of Tristan, as well as her clarion call for freedom for all who were oppressed, and they set the tone for her travel account. Therefore, the complete removal of these three sections by Hawkes in her abridged English translation seriously weakens Tristan's principal message.

In her Translator's Note, Hawkes (1986b: xxix) states that her decision not to include the three preliminary sections, thereby cutting out a third of the original text, was motivated by "considerations of space and economy" as the original text has "908 pages and runs to over 180,000 words." She claimed that, although she had omitted the preliminary sections altogether, she had summarized the pertinent information in her introduction (Hawkes 1986a). However, an examination of her text casts doubt on this claim. For example, Hawkes avoided mentioning any association between marriage and slavery. She did refer to Tristan's pioneering act of exposing her personal woes and calling upon other women to do the same. Hawkes' summary of Peregrinations was as follows: "This was the story of her visit to Peru in 1833-1834 to claim her share of the family fortune, a journey she undertook as a last desperate resort after leaving her husband Andre Chazal and trying for eight years to support herself and her children" (Hawkes 1986a: x). Tristan did not want her story to be about a search for financial security. Hawkes (1986a: xviii) commented that Tristan's 22-page Preface was "more remarkable for grandiloquence than logic;" yet, 
by not translating this section, she does not allow readers to form their own opinion. Hawkes also remarked that Tristan was too emotional and exasperating sometimes, a view that affected Hawkes' decisions about editing the text.

Additionally, Hawkes's Translator's Note alerts readers about omissions she made in her abridged version. Hawkes makes some critical decisions in relation to the source text:

In the narrative proper, I have eliminated a number of minor characters....and the ladies Tristan met in Lima, including Calista Thwaite, who translated Byron in Spanish, and Caroline Riva Aguero, the Dutch wife of the first president of Peru. I have cut much of Tristan's moralizing, telescoped descriptions of people and places, and excised a long conversation about politics between the officers of the Mexicain. These cuts vary in length from a few words (superfluous adjectives, pious exclamations, etc.) to twenty-five pages (letters...she quotes in full) [...] An abridgement seldom satisfies anyone who knows the original work, but I trust there is enough of Flora's attractive and contradictory personality in these pages to engage the interest and the affection of readers, even if, like me, they find her exasperating at times. (Hawkes 1986b: xxix-xxx)

In sum, readers get the sense that Hawkes was more interested in presenting the main issues at hand without incorporating too much sentimentality and self-righteous indignation. Perhaps, her decision to dampen the emotional content was to counteract the perception that the tone of Pérégrinations was too dramatic or overwrought.

Hawkes' introduction is to be commended for providing additional information about Peru's political upheavals before Tristan's arrival. She further added that Tristan's publication of Pérégrinations was in retaliation for her husband's memoir $(1838)^{8}$ about her being an unfaithful wife and unfit mother. Hawkes also praised her inquiring mind and observational skills while noting an inability to capture fully the Peruvian landscape. For Hawkes, Peregrinations was more than a travel account, it was "a personal odyssey, a record of temptations [Flora Tristan] had to face in the course of her transformation from a self-centred young woman into a single-minded champion of the oppressed" (Hawkes 1986a: x-xi). She concluded her introduction with a brief review of her other literary works. Hawkes' introduction gives a general overview of Tristan the author but underrepresents her state of mind and her radical stance towards marriage, divorce, slavery, and women's rights. In the next section, analysis of the main text in volume I is provided.

\subsubsection{Selected passages from Volume I}

This section examines selected passages on marriage and slavery in volume I. The first passage to be considered is Tristan's encounter with the Portuguese slave port, La Praya (Praia), off Cape Verde in Chapter 2. This was her first encounter with land after setting sail from France. Her racist reaction to the presence of slaves in this instance strongly contradicted the anti-slavery image Tristan sought to portray:

7) Toute la population était dans les rues, respirant le frais devant les portes des maisons; nous fûmes alors assaillis par l'odeur de nègre, on ne saurait la comparer à rien, elle soulève le cœur, elle vous poursuit partout. Entre-t-on dans une maison, on est à l'instant saisi par cette émanation fétide. Si l'on s'approche de quelques enfants pour voir leurs jeux, vite on s'éloigne, tant l'odeur qui s'en exhale est repoussante. Moi, dont les sens sont très susceptibles, à qui la moindre senteur porte à la 
tête ou à l'estomac, j'éprouvais un malaise tellement insupportable, que nous fûmes forcés de précipiter notre marche afin de nous trouver hors d'atteinte de ces exhalaisons africaines.

(Tristan 1838a: 41-42; author's emphasis)

a) Toda la población se hallaba en las calles, respirando el fresco delante de las puertas de sus casas. Entonces sentimos el olor de negro, que no puede compararse con nada, que da náuseas, and persigue por todas partes. Se entra en una casa y al instante siente uno esa emanación fétida. Si uno se acerca a algunos niños para ver sus juegos, tiene que alejarse rápidamente, ¡tan repugnante es el olor que exhalan! Yo tengo los sentidos muy aguzados y el menor olor se me va a la cabeza o al estómago. Sentía un malestar tan insoportable que nos vimos obligados a precipitar la marcha para encontrarnos fuera del alcance de aquellas exhalaciones africanas.

(Tristan 1838/2003: 114-115, translated by Romero; author's emphasis)

b) The entire population seemed to be out on their doorstep for a breath of fresh air, and it was then that we first became aware of the characteristic negro smell: there is nothing like it, it follows you everywhere you go. If you approach a group of children to watch them play, you have to beat a hasty retreat, the odour they give off is repellent. As for me, I am particularly sensitive and the slightest smell affects my head or stomach, so we had to quicken our pace to escape from the effluvium Africanum.

(Tristan 1838/1986: 17-18, translated by Hawkes; author's emphasis)

Romero's literal translation did not omit or paraphrase anything. Hawkes's translation into English, while capturing Tristan's reaction, did not translate everything the author wrote. Hawkes tried to soften the language by not highlighting the so-called smell of the negro and using effluvium Africanum, a unique Latin term to replace the plural exhalaisons africaines.

Additional information about Tristan's opinions about slaves and slavery was provided by her conversation with the Frenchman M. Tappe, a missionary turned slave-trader. Tristan was repelled by his wicked and inhuman attitude to slaves. In her opinion, he was no longer human, but rather le mouton anthropophage (carnero antropófago, cannibal sheep). To her credit, she referred to slavery as ce monstrueux outrage à l'humanité (Tristan 1838a: 70) - rendered that monstrous outrage against humanity (Tristan 1838/1986: 29) in English and ese monstroso ultraje a la humanidad (Tristan 1838/2003: 129) in Spanish - and talked about the paralyzing effect of slavery on the enslaved. She also intervened in the beating of a slave. In Paulk's reading of Tristan's initial reaction to slaves in Praia, she affirms that "even though she is guilty of the same racism that justified the practice of slavery, Tristan deplores the institution itself" (Paulk 2010:124). The English translation by Hawkes omitted the crew's encounter with Brandisco, a slave trader/goods trader who tried to sell them two of his slaves. Hawkes also omitted Flora's monologue about the destructive effect of slavery on Praia's population who were malnourished, plagued by numerous diseases and suffered a high mortality rate.

As usual, Tristan did not pass up any chance to highlight her enslavement to her husband. Throughout her voyage she would look keenly for signs of oppression. After the crew embarked at Praia (Chapter 3), Tristan contemplated a relationship with the ship's captain, Chabrié, a man who, she believed, loved her truly: 
8) Moi m’unir à un être dont je me sentais aimée, impossible! Une voix infernale me répétait avec un ricanement affreux: «Tu es mariée! C'est à un être méprisable, il est vrai; mais enchaînée à lui pour le reste de tes jours, tu ne peux te soustraire à son joug. Pèse la chaîne qui te fait son esclave et vois si, plus qu'à Paris, tu peux la rompre!»

(Tristan 1838a: 105)

a) ¡Yo, reunirme a un ser de quien me sentía amada! ¡Imposible! Una voz infernal me repetía con una risa burlona. "Tú eres casada. Con un ser despreciable, es cierto, pero encadenada a él por el resto de tus días, y no puedes sustraerte a su yugo. Pesa la cadena que te hace su esclava y ve si mejor que en Paris la puedes romper."

(Tristan 1838/2003: 145, translated by Romero)

b) An infernal mocking voice kept repeating: 'You are married! Married to a contemptible creature, it is true; but you are chained to him for the rest of your days, and you cannot break that chain here anymore than you could in Paris!

(Tristan 1838/1986: 39, translated by Hawkes)

Hawkes omits Tristan's exclamation about the impossibility of her union with Chabrié, the man who loves her. This is in line with Hawkes's choice to eliminate overly emotional texts. Additionally, the English translation reduced the emotional tone, avoiding the use of slave and yoke to translate the original, and only using the word chain to express the sense of imprisonment. Later, Tristan fantasized about a happy relationship with Chabrié and their probable residence in California, and she blamed absurd laws and man's machinations for being responsible for slavery and indissolubility of marriage. Tristan makes the point that a fugitive slave is no more a criminal than a married woman fleeing her husband.

9) J'entends des gens confortablement établis dans leur ménage, où ils vivent heureux et honorés, se récrier sur les conséquences de la bigamie, et appeler les mépris et la honte sur l'individu qui s'en rend coupable. Mais qui fait le crime, si ce n'est l'absurde loi qui établit l'indissolubilité du mariage? Sommes-nous donc tous semblables en nos affections, nos penchants, lorsque nos personnes sont si diverses, pour que les promesses du cœur, volontaires ou forcées, soient assimilées aux contrats qui ont la propriété pour objet? Dieu, qui a mis dans le sein de ses créatures des sympathies et des antipathies, en-a-t-il condamné aucune à l'esclavage ou à la stérilité? L'esclave fugitif est-il criminel à ses yeux? le devient-il lorsqu'il suit les impressions de son cœur, la loi de la création?...

(Tristan 1838a: 155-156)

a) Comprendo que las gentes cómodamente establecidas en su hogar en el que viven felices y honrados se admiren por las consecuencias de bigamia y sientan desprecio y vergüenza por el individuo que incurra en culpa. Pero ¿quién comete el crimen si no es la absurda ley que establece la indisolubilidad del matrimonio? Siendo nuestras personas tan diversas, ¿somos acaso todos tan semejantes en nuestros afectos y en nuestras inclinaciones para que las promesas del corazón, voluntarias o forzadas, sean asimiladas a los contratos relativos a la propiedad? Dios ha puesto en el seno de sus criaturas simpatías y antipatías, ¿acaso ha condenado a alguna a la esclavitud o la esterilidad? El esclavo fugitivo ¿es criminal a sus ojos?, ¿lo es cuando sigue las impresiones de su corazón y la ley de creación?...

(Tristan 1838/2003: 170, translated by Romero) 
b) I can hear people comfortably settled in respectable married bliss protesting against the consequences of bigamy and demanding that anyone guilty of such shameful conduct should be treated with contempt. But wherein lies the crime, if not the absurd law which makes marriage indissoluble? Are we all so alike in our affections and inclinations that affairs of the heart should be treated in the same way as affairs of business?

(Tristan 1838/1986: 52, translated by Hawkes)

Hawkes did not translate Tristan's allusion of her marriage circumstance to that of a fugitive slave, perhaps considering it to be another example of Tristan's tendency to exaggerate.

Hawkes informs the readers that she eliminated some minor characters while editing, although she fails to mention them by name, including the Frenchwoman, Madame Aubrit (in Chapter 4). In the English version, she owned a guesthouse in the Chilean sea-port town of Valparaiso that had a high rate of French immigration. Madame Aubrit was more than a hotel owner for Tristan, she was an example that marriage in France makes women second-class citizens as they suffer many injustices. Tristan informed readers of her resilience, and the trials and hardship she endured after running away from her husband. She eloped to Valparaiso with a young man who died after six months, leaving her pregnant. She preferred to stay in an unknown country rather than return to France where she was a pariah. As a prosperous woman running her own business, however, to Tristan, she was a symbol of female power, strength, and stamina.

10) Madame Aubrit est aussi une des victimes du mariage. Mariée, à seize ans, avec un vieux militaire dont le caractère et les mœurs lui étaient antipathiques, l'infortunée jeune femme eut beaucoup à souffrir. A la fin, ne pouvant plus endurer cet enfer, elle y échappa par la fuite... Madame Aubrit, en quittant son mari, resta sans moyen d'existence. Elle voulut gagner sa vie, mais que faire? Pour les femmes toutes les portes ne sont-elles pas fermées? ... L'histoire de Madame Aubrit est celle de milliers de femmes, comme elle, en dehors de la société, et qui ont, de même, toutes les horreurs de la misère et de l'abandon à souffrir. Notre société reste insensible à la vue de ces misères et de la perversité qu'elles font naître.

(Tristan 1838a: 174-177)

a) Mme. Aubrit es también una de las víctimas del matrimonio. Casada a los dieciséis años con un viejo militar cuyo carácter y costumbres le eran antipáticos, la infortunada joven tuvo mucho que sufrir. Al fin, no pudo ya soportar aquel infierno, se escapó y huyó... Mme. Aubrit al dejar a su marido quedó sin medios de subsistencia. Quiso ganarse la vida, pero ¿qué hacer? Para las mujeres ¿no están cerradas todas las puertas?... La historia de Mme. Aubrit es la de miles de mujeres, como ella, que están al margen de la sociedad y tienen que sufrir los horrores de la miseria y del abandono. Nuestra sociedad se muestra insensible a la vista de estas desgracias y a la perversidad que las hace nacer.

(Tristan 1838/2003: 181-182, translated by Romero)

Tristan used strong words such as victimes du mariage (victims of marriage) and infortunée (unfortunate) to describe the state of thousands of women such as Madame Aubrit. She refers to marriage as a hell, horror, and misery women suffer. In this quote, Tristan blamed society for its complicity in the hardship, poverty, and abandonment that women endured by closing the doors of opportunity, hence pre- 
venting the advancement of abused women. While Romero provides a faithful translation in Spanish, readers are denied this portrait in the English translation. There is no mention of Madame Aubrit in Hawkes's main text and Translator's Note. Hawkes denied Tristan the opportunity to back her claim that marriage was oppressive to other women as well.

In contrast, when translating the story of Flora's cousin, Carmen, in Arequipa (Chapter 8), another tale of marriage enslavement, Hawkes preserved the language and wording of the original, using words such torture, yoke, slave, tyranny, oppression, masters, victim, and torture to describe the plight of women. Her translation transmitted the heightened tone of desperation, caused by the indissolubility of marriage, found in the original text. Furthermore, she faithfully translated the original text's depiction of the racial hierarchies as white (European), brown (Indian), black (Negro), and coloured. She even translated Tristan's mockery of "several ladies who passed as white, although their skin was the colour of gingerbread" (Tristan 1838/1986: 127).

Tristan commented on the processions during Holy Week which she considered vulgar and unspiritual. Her racist statements showed her contradictory nature to slavery. For example:

11) Les esclaves participent aussi à ces amusements: ils se jettent de la farine, ce mode d'attaque est plus économique; aussi beaucoup de gens en font usage. Toutes ces négresses avec leur peau noire, les cheveux crépus, barbouillées de la farine sont hideuses! Le soir, on se réunit dans ces bals où les danses plus indécentes sont exécutées.

(Tristan 1838a: 368; author's emphasis)

a) Los esclavos también participan en estas diversiones; se echan harina. Este modo de atacar es muy cómico y lo emplean muchas personas. Por la tarde, asisten a bailes donde se ejecutan aún más indecentes.

(Tristan 1838/2003: 286, translated by Romero)

b) The slaves too share in the fun: they throw flour at each other, as this is more economical - in fact many other people do the same. In the evening, everybody goes off to balls where the most indecent dances are performed.

(Tristan 1838/1986: 126, translated by Hawkes)

In this selected passage, Tristan made a racist comment, referring to négresses, with their black skin and kinky hair, as hideous. Both Hawkes and Romero omitted this particular racist sentence in their translations. This omission is ethically questionable as it acts to cover-up a racist attitude by the author. On a lighter note, Romero changes the adjective économique (economical) to cómico (funny), which in no major way affects the general sense of the sentence. However, the original text pointed out the fact that flour was a cheaper alternative to paint-filled eggs. In the following section, selected passages in the second volume are analyzed.

\subsubsection{Selected passages in Volume II}

Tristan described the epic escape of her cousin, Dominga, from the convent of Santa Rosa (in Chapters 3 and 5). Both translations reveal her admiration and support for her cousin and her criticism of society for its ignorance and superstition in isolating her. They also record a sense of frustration from the reaction of the local people, including her own family (only two members supported her), who refused to allow 
her to reintegrate into society. She was constantly reminded of her status as a nun wherever she went.

Chapter 8 recounts the story of the powerful, smart, superior, and very free women of Lima. Both translations captured Tristan's envy or desire for their freedom, and her appreciation of their charms and their unique dressing outfit, the saya $y$ manto. They also captured her criticism of these women's lack of education. However, Hawkes' English translation omitted the three women whom the author considered to be the most distinguished in Lima: Mme Riva Aguero, Calista Thwaites, and Manuela Ricos. Although, in her Note, she says she omitted "ladies Tristan met in Lima" (Hawkes 1986b: xxix), her description of these ladies did not do them justice. For instance, she wrote that Calista "translated Byron to Spanish" (Hawkes 1986b: xxix) and that Caroline Riva Aguero was the "Dutch wife of the first president of Peru" (Hawkes 1986b: xxix), but this is just part of the story.

12) Parmi les femmes distinguées que renferme Lima, j'en citerai trois dont, en parlant de cette ville, je ne saurais omettre les noms. La première est madame de la RivaAguero, célèbre par ses malheurs, par le courage et la constance qu'elle montre à les supporter. La seconde est madame Calista Thwaites, la femme la plus instruite que j’aie rencontrée en Amérique, et que distinguent également le brillant de son esprit, la justesse de son jugement. Et, enfin, la troisième est Manuela Riclos, femme savante, très spirituelle, dit-on, mais encore plus pédante.

(Tristan 1838b: 389)

a) Entre las mujeres distinguidas que viven en Lima citaré a tres cuyos nombres no podría omitir al hablar de esta ciudad. La primera es la señora de la Riva Agüero, célebre por sus desgracias y por el valor y la constancia que demuestra al soportarlas. La segunda es la señora Calixta Thwaites, la mujer más instruida que he encontrado en América y que se distingue por su espíritu brillante y la exactitud de sus juicios. Y, por fin, la tercera es la señora Manuela Riglos, mujer sabia y muy espiritual, según dicen, pero más pedante aún.

(Tristan 1838/2003: 501, translated by Romero)

The role of the three women in the theme of the book was related mostly to their superiority over the men of their generation. Nonetheless, the story of la señora de la Riva-Aguero fits into Tristan's theme that women are marital slaves.

13) Madame de la Riva-Aguero (Caroline Delooz) appartient à une des premières familles de la Hollande, où elle est née. Elle a reçu une éducation aussi brillante que solide... C'est une femme accomplie... En 1822, arriva à Bruxelles un péruvien nommé de la Riva-Aguero; il s'introduisit...dans la famille de la jeune Caroline Delooz, s'y présenta avec un cortège de titres et se donna pour le président de la république du Pérou... Devenu amoureux de Caroline, il la demanda. M. Delooz... le noble et ambitieux Hollandais... accueillit sa demande... Riva-Aguero avait alors cinquante-cinq ans, était d'une laideur repoussante, d'une santé chancelante, d'un caractère triste et sévère. La jeune personne, le désespoir dans le cœur, alla se jeter aux pieds de sa mère et lui demanda protection; mais, hélas! la pauvre mère, esclave comme sa fille, ne pouvait que confondre ses larmes avec celles de son enfant. Le noble époux, maître absolu dans sa famille, vit se taire devant sa volonté toutes les répugnances... Cette société hollandaise, encore plus asservie que la nôtre aux préjugés de l'orgueil, trouvait que le président du Pérou était un très beau parti pour Caroline Delooz... Elle avait dix-sept ans quand elle épousa le vieillard... Elle arriva... à Lima. Ah! quel dut être l'amer désespoir de cette jeune femme à la vue 
de la petite maison dans laquelle l'établit son mari...M. de la Riva-Aguero avait menti en se donnant pour président de la république du Pérou: il est vrai que, dans un mouvement populaire, une nomination extra-légale lui avait donné ce titre. Il le conserva trois jours au milieu du désordre auquel il le devait.

(Tristan 1838b: 390-394; author's emphasis)

a) La señora de la Riva-Agüero (Carolina Delooz) pertenecía a una de las primeras familias de Holanda, en donde nació. Recibió una educación tan brillante como sólida... Era una mujer completa... En 1822 llegó a Bruselas un peruano llamado de la Riva-Agüero. Se introdujo... en la familia de la joven Carolina Delooz; se presentó con un cortejo de títulos y se dio de Presidente de la República del Perú... M. Delooz...el noble y ambicioso holandés... acogió su pedido... Riva Agüero tenía entonces cincuenta y cinco años, era de una repugnante fealdad, de mala salud y de carácter triste y severo. La joven con la desesperación en el alma fue a echarse a los pies de su madre y a pedirle protección. Pero ¡ay! la pobre madre, esclava como su hija, no podía sino confundir sus lágrimas con las de su niña. El noble esposo, amo absoluto de su familia, vio callar ante su voluntad todas las resistencias... La sociedad holandesa, aún más esclavizada que la nuestra por los prejuicios del orgullo, encontraba que el Presidente del Perú era un excelente partido para Carolina Delooz... Llegó...a Lima. ¡Ah! Cuál debió ser la desesperación de esta joven a la vista de la casa en donde la instaló su marido... Es verdad que durante un movimiento revolucionario un nombramiento extralegal le había dado aquel título. Lo conservó tres días en medio del desorden al que lo debió.

(Tristan 1838/2003: 502-504, translated by Romero)

In this long quote, Tristan once again identified with women in forced marriages. She referred to Caroline Delooz and her mother as slaves and wrote that in Dutch society women were even more enslaved than in France. Tristan projected her trials onto other women, as if to prove that she was not the only one in this situation. This supported her assertion that women were universally enslaved.

The Spanish translation by Romero omitted the phrase that M. de la Riva-Agüero fell in love with Carolina and hence asked to marry her. This could have been an oversight, but several corrections made by Romero in relation to this story suggest that it might have been deliberate. Romero provided a footnote that clarified the situation. It affirmed that princess Caroline Arnoldina de Looz-Corswaren was Belgian, yet born in Holland, and whose father was a Duke. Romero further stated that Tristan gave an erroneous date about the expatriation of Riva-Agüero and that it should be 1824. In addition, Riva-Agüero was a little over forty years old and not fifty-five as claimed by Tristan. Also, Romero contradicted Tristan's portrayal of Riva-Agüero as a liar or scheming man who deliberately misled the family of Carolina Delooz. Romero claimed that Riva-Agüero played an important role in the fight for independence against Spain. He was elected the first president of Peru on January 28, 1823 and was deposed on July 23, 1823 by the same Congress. After a four-year spell of exile/expatriation in Europe, he returned and held some high level governmental positions. In light of this information, it seems possible that Tristan repeated this story from an unreliable source. This is an example of the usefulness of Romero's footnotes in correcting/clarifying details.

Chapter 9 concludes with Tristan's last encounter with slavery before she returned to France. She visited the Lavalle sugar refinery and had a long conversation 
with the owner. Her stance against racism was clear in this encounter. She believed in the gradual emancipation of slaves, a position similar to that of the abolitionist movement of her time. She wanted sugar beets to become a reliable source of sugar production so as to decrease or eliminate slave labour. She visited a cell where two négresses had been imprisoned for infanticide and refers to one of the slaves as "very beautiful" with "a proud noble soul," who belonged to the group of negroes with "indomitable spirits who suffer torments and die without ever submitting to the yoke" (Tristan 1838/1986: 286). Therefore, Tristan positioned herself as a voice against slavery and oppression.

Both the Spanish and English translations were faithful to the original text in this instance, and accurately conveyed Tristan's emotionality against slavery. A footnote by Romero indicates that General Ramon Castilla abolished slavery in Peru on December 5, 1854, some twenty years after Tristan's visit.

\section{Translation styles, analysis, and conclusions}

The question as to which translation approach is the best has plagued translators and academics for a long time. Whereas critics differ in perspective, many share the belief that the principal idea that should guide a translator is the transmission or conversion of meaning. Hoberman (1985: 58) believes that a good translation is a conscious and competent effort to transmit fully the meaning of the original text without including additional meaning. For him, it is a matter of intellectual honesty. As discussed in detail above, Romero and Hawkes, the two translators studied here, decided to delete a racist statement from the text, and Hawkes decided to do an abridged English translation of Pérégrinations d'une paria. Ethically, according to Antoine Berman (cited in Simon 1996: 36), a translator is at liberty to do as she is ideologically inclined so long as she is open about her intentions with the source text. Although Hawkes informed readers in her Note that she removed some emotionally charged and moralizing content in her abridged English edition, she did not provide enough information as to what that entailed. Even though she indicated her omission of certain characters, a more detailed description of that process in the Translator's Note would have been needed. Romero and Hawkes, like all translators, were faced with several important decisions as they determined the best approach for the purpose of their work. Having decided to whom they owed their loyalty, they had to negotiate between the author and her text, the target audience and the text, and finally the organization publishing the translation. In all likelihood, this process also involved some linguistic, cultural, economic, and ideological considerations in relation to the choice of grammar, vocabulary, syntax, structure, and the tone or effect of the text.

Both Romero and Hawkes were not invisible translators as defined by Venuti (1995: 1). In her introduction and Translator's Note, Hawkes documented the decisions she made. She provided a critical analysis of Tristan that, in a way, alerted readers to her excessive and exasperating nature. In this way, she may have influenced readers on how to interpret the book. Romero, for her part, inserted footnotes beginning in the preface and continuing throughout the book. These provided supplementary information and recommended readings, as well as correcting factual errors made by the author. Some critics believe that it is not the translator's role or responsibility to provide extra information, but many academic translators do this. 
Romero and Hawkes can be evaluated as per the criteria described by Luise von Flotow (1991) for feminist translators. Von Flotow identifies three main practices used by feminist translators. The first, supplementing, is when translators add additional information to make the text clearer to the reader. The second, prefacing and footnoting, the most popular of the three, calls attention to the work of the translation as well as explains the translator's decisions. The third, hijacking, is when the translator manipulates, changes, or politicizes the text contrary to the intentions of the author. Based on these criteria, Romero and Hawkes did not supplement their translations of Pérégrinations d'une paria, but they did use footnotes and prefacing, respectively. Romero faithfully translated the French text into Spanish, and did not hijack the text. However, there was some degree of inverse hijacking in Hawkes' English translation as, already convinced of the excessive emotional content of the original text, she decided to neutralize it for the most part. She also hijacked one of the principal themes of Tristan's book, the association of marriage with slavery, a point that was so important to her that she reiterated it many times. This decision to excise this connection between marriage and slavery does indeed qualify as hijacking.

Closely associated to these points is the question of fidelity or equivalence in translation. Is there such a thing as absolute fidelity in translation? Romero's Spanish translation is very faithful to the original, not only in meaning but in form, as she clearly used a literally or formally equivalent style. Although her choice of diction and structure fairly resembled the original, sometimes longer sentences are restructured into many shorter sentences. Hawkes' style is one of dynamic equivalence; she employed natural, contemporary English. She transmitted the main ideas of the book, but she decided to dampen the emotional tone of Tristan's writing style. In spite of the abridged nature of her version, Hawkes still portrayed the author as a strong advocate for women's rights. Her decision to condense the book may have been influenced by her commercial partner, Virago in terms of economy and space.

In conclusion, Romero and Hawkes are skilled translators who took different approaches towards Tristan's Pérégrinations d'une paria. Romero translated the entire book into Spanish, being very faithful to the original text in both meaning and form. In doing so, she did not dampen the emotionality of Tristan's writing or diminish her association of marriage with slavery, but she did, however, remove at least one racist comment by Tristan. The translator also provided informative footnotes in the text that gave additional information and corrected factual inaccuracies in the original. Taken together, these characteristics of Romero's translation make it attractive for academic use. Hawkes, on the other hand, decided to produce an abridged English edition that eliminated about one-third of the original. By not including the Dedication, Prologue, and Foreword, this abridged edition omitted important information about the philosophy, beliefs, and projected image of Tristan. Hawkes made a conscious decision to decrease the emotionality of her writing, and she removed the repeated association of marriage with slavery. More than Romero, Hawkes deleted and softened some of the racist statements made by Tristan. This translator provided a useful Introduction and Note with her translation, but did not use footnotes. The abridged nature of Hawkes' English translation and her editorial decisions limit its usefulness as source material for academic study, but make it more attractive commercially as a book targeted for the general public. 
Certainly, Romero and Hawkes inhabited "two different rooms" when it came to the translation of Tristan's Pérégrinations d'une paria. Romero allowed Tristan to express her outrage, frustrations, grievances, pains, emotions, exclamations, hyperboles, and indignations about the indissolubility of marriage and low status of women in society. Her Spanish translation gave Tristan the platform to portray women as slaves of marriage universally and show women as superior to men intellectually. She showed Spanish readers how strongly Tristan felt about society's treatment of women who dared to flee their unhappy marriages. She preferred to use footnotes to make her points. Hawkes was more interested in relaying Tristan's story without the excessive emotions, repetitions, and moralizing. In so doing, she diminished Tristan's principal message that marriage, backed by societal laws, enslaved women. Hawkes diluted Tristan's message that being a woman is to be a slave by omitting Tristan's comparisons between marriage and slavery. In spite of the two approaches, both translations have been widely received and are valuable texts for research.

\section{NOTES}

1. Tristan, Flora (1838a): Pérégrinations d'une Paria (1833-1834). Vol. 1. Paris: Arthus Bertrand. Tristan, Flora (1838b): Pérégrinations d'une Paria (1833-1834). Vol. 2. Paris: Arthus Bertrand.

2. Tristan, Flora (1838/1986): Peregrinations of a Pariah. (Translated by Jean Hawkes). London: Virago Press Limited.

3. Tristan, Flora (1838/2003): Peregrinaciones de una Paria. (Translated by Emilia Romero). Lima: Centro de la Mujer Peruana Flora Tristán/UNMSM, Fondo Editorial.

4. Tristan, Flora (1838/1941): Peregrinaciones de una paria. (Translated by Emilia Romero) Santiago de Chile: Ercilla.

5. Tristan, Flora (1838/1946): Peregrinaciones de una paria. (Translated by Emilia Romero) Lima: Editorial Cultura Antártica S.A.

6. Tristan, Flora (1838/1986): Peregrinations of a Pariah. (Translated by Charles SAlis) London: Folio Society.

7. Tristan, Flora (1838/1980): Les pérégrinations d’une paria, 1833-1934. La Découverte. Paris: Maspero.

8. Favre, Jules (1838): Mémoire à consulter. Pour M. Chazal contre madame Chazal. Paris: Cosson.

\section{REFERENCES}

André, María Claudia and Bueno, Eva Paulino (2014): Latin American Women Writers: An Encyclopedia. London/New York: Routledge.

Cross, Maire (2007): Flora Tristan. Pérégrinations d'une Paria. The Romanic Review. 98(1):103105.

Grogan, Susan (1998): Flora Tristán: Life Stories. London/New York: Routledge.

GuiÑazú, Cristina (2002): En el nombre del padre: Las peregrinaciones de una paria de Flora Tristán. Ciberletras: Revista de crítica literaria y de cultura. 5. Visited 10 April 2016, <http:// www.lehman.cuny.edu/ciberletras/v05/guinazu.html>.

Hawkes, Jean (1986a): Introduction. In: Flora Tristan. Peregrinations of a Pariah 1833-1834. (Translated by Jean Hawkes) London: Virago Press Limited, ix-xxviii.

Hawkes, Jean (1986b): Translator's Note. In: Flora Tristan. Peregrinations of a Pariah 1833-1834. (Translated by Jean Hawkes) London: Virago Press Limited, xxix-xxxi.

Hoberman, Barry (1985): Translating the Bible. The Atlantic Monthly. 255(2):43-58.

Law-Sullivan, Jennifer (2010): Liberté, Égalité, Sororité: Flora Tristan and the Contact Zone between Race \& Gender. Nineteenth-Century French Studies. 39(1-2):62-76.

Kadish, Doris and Massardier-Kenney, Françoise, eds. (1994). Translating Slavery: Gender and Race in French Women's Writing 1783-1823. Kent, Ohio: Kent State University Press, 11-61. 
Kadish, Doris and Massardier-Kenney, Françoise eds. (1994/2009). Translating Slavery: Gender and Race in French Abolitionist Writing 1780-1830. $2^{\text {nd }}$ ed. Kent: Kent State University Press, 3-64.

Massardier-Kenney, Françoise (1994/2009): Translation Theory and Practice. In: Doris Kadish and Françoise Massardier-Kenney, eds. Translating Slavery: Gender and Race in French Abolitionist Writing, 1780-1830. Vol. 1. Kent: Kent State University Press, 3-18.

Neubert, Albrecht and Shreve, Gregory M. (1994): "A House of Many Rooms": The Range of Translation Studies. In: Doris Kadish and Françoise Massardier-Kenney, eds. Translating Slavery: Gender and Race in French Women's Writing 1783-1823. Kent: Kent State University Press: vii-xiv.

PAULK, Julia (2010): Representations of Slavery and Afro-Peruvians in Flora Tristán's Travel Narrative, Peregrinations of a Pariah. Afro-Hispanic Review. 29(1):117-134.

Puech, Jules-L. (1925): La Vie et l'oeuvre de Flora Tristan. Paris: Marcel Rivière.

Richardson, Joanna (1986): Introduction. In: Flora Tristan. Peregrinations of a Pariah. (Translated by Charles SALIS) London: Folio Society, iii-xv.

Simon, Sherry (1996): Taking Gendered Positions in Translation Theory. In: Sherry Simon. Gender in Translation: Cultural Identity and the Politics of Transmission. London/New York: Routledge, 1-38.

Venuti, Lawrence (1995): The Translator's Invisibility: A History of Translation. London/New York: Routledge.

Von Flotow, Luise (1991): Feminist Translation: Contexts, Practices and Theories. TTR. 4(2):6984. 